\title{
The Thymus in "Bare Lymphocyte"Syndrome: Significance of Expression of Major Histocompatibility Complex Antigens on Thymic Epithelial Cells in Intrathymic T-Cell Maturation
}

\author{
Henk-Jan Schuurman, Frank P. van de Wijngaert, \\ Jonne Huber, Ruud K.B. Schuurman, Ben J.M. Zegers, \\ John J. Roord, and Louis Kater
}

ABSTRACT: Thymic biopsies from two patients with combined immunodeficiency and defective expression of HLA class I and class II antigens on blood mononuclear cells ("bare lympbocyte" syndrome) were investigated. This made possible an evaluation of the significance of HLA antigen expression in a detailed (immuno)bistologic study. Both thymuses showed a normal lobular architecture with distinct cortex-medulla areas, well-differentiated epitbelium, including ultrastructurally defined subtypes, and Hassall's corpuscles. Normal numbers of lymphoid cells were present and normal T-cell phenotype was found. Using anti-HLA-A,B,C antisera, confluent staining of the medulla (stroma and lymphocytes) was observed. One of the thymuses was found to be negative for HLA class II antigen expression: the other revealed only HLA-DR positivity of nonlymphoid cells in the medulla. These cells were not of epithelial nature as judged from double staining with anti-keratin antibody. There was no expression of $H L A-D C / D S$. These observations differ from findings in the normal thymus, wherein epithelial cells in the cortex carry HLA class I and class II antigens, and epithelial cells in the medulla express HLA class 1 , and for a minor part class II antigens. The results indicate a normal sequential acquisition of $T$-cell differentiation antigens in the thymus of both cases. It is suggested that the expression of HLA class I and class II antigens on epitbelial cells in the normal thymus cortex does not play a significant role in the sequential acquisition of differentiation antigens on $T$ lymphocytes.

\section{ABBREVIATIONS}

$\begin{array}{llll}\text { ConA } & \text { concanavalin A } & \text { PHA } & \text { phytohemagglutinin } \\ \text { FITC } & \text { fluorescein isothiocyanate } & \text { PNA } & \text { peanut agglutinin } \\ \text { HLA } & \text { human leucocyte antigen } & \text { PWM } & \text { pokeweed mitogen } \\ \text { Ig } & \text { immunoglobulin } & \text { TdT } & \begin{array}{c}\text { terminal deoxynucleotidyl } \\ \text { transferase } \\ \text { MHC }\end{array} \\ \text { major histocompatibility } & \text { complex } & \text { TRITC } & \begin{array}{c}\text { tetramethyl rhodamin } \\ \text { isothiocyanate }\end{array} \\ \text { PBS } & \text { phosphate buffered saline } & & \end{array}$

From the Division of Immunopathology, Department of Internal Medicine and Institute for Pathology, University Hospital, Utrecht: the Department of Immunobematology, University Medical Center, Leiden: and the Department of Immunology, University Children's Hospital "Het Wilbelmina Kinderziekenbuis," Utrecht, The Netherlands.

Address requests for reprints to H.J. Schuurman, Ph.D., Division of Immunopatbology, Department of Internal Medicine, University Hospital, 101 Catbarijnesingel, $3511 \mathrm{GV}$ Utrecht, The Netberlands.

Accepted November 6, 1984. 


\section{INTRODUCTION}

Products of the MHC are essential for cell-cell interactions in the afferent and effector phase of the immune response. Immune recognition by $\mathrm{T}$ lymphocytes requires the simultaneous recognition of antigen and $M H C$ antigens $[1,2]$. The thymus appears to be the privileged site for restriction or amplification of $\mathrm{T}$ lymphocytes with self-MHC receptors $[3,4]$. Within the thymus $T$ cell maturation takes place by direct cell-cell contact between precursor $T$ cells and nonlymphoid thymic matrix cells; humoral factors synthesized by thymic epithelial cells also play a role in this process $[5,6]$. Studies on phenotype and functional capacity of thymocytes have provided evidence that lymphocyte-epithelial cell contact occurs in the cortex. The medullary epithelial cells mainly act as thymic humoral factor-producing cells [6].

Epithelial cells in the thymic cortex express class I and class II MHC antigens $[7,8]$. According to some authors [6,9], epithelial cells in the medulla do not express class II antigens. Nude mice lack MHC class II antigen expression on epithelial cells in their thymus rudiment. Therefore, MHC class II antigen expression by epithelial cells is concluded to be involved in the development of $\mathrm{T}$ lymphocytes within the thymus [10].

Patients with combined immunodeficiency disease associated with defective expression of HLA of class I and in some cases also of class II on blood mononuclear cells (so-called "bare lymphocyte" syndrome) have been described [11-17]. Concordant with studies in mice [3,4], the association between defective HLA antigen expression and combined immunodeficiency suggests immunological significance of HLA antigens in the development of a functional T-cell system [15].

We investigated thymic biopsies from two patients with "bare lymphocyte" syndrome $[12,13,16,17]$ to evaluate intrathymic T-cell maturation in more detail. In particular, we studied the expression of HLA antigens in various cell populations of the thymus.

\section{METHODS}

Patients and controls. Immunological data of the two male patients KD [13] and TF $[12,16,17]$ have been described previously and are summarized in Table 1. Both cases were diagnosed as combined immunodeficiency. A thymus biopsy was obtained from KD at the age of 2 years and from TF at 7 months of age. At the time of thymus biopsy both patients suffered from a Pneumocystis carinii infection, and TF had oral candidiasis. These infections could be treated successfully.

Several thymic biopsies (at least 3) from patients undergoing cardiac surgery served as control tissue (age range of donors was 6 months -3 years). All control samples showed a normal architecture in routine histology.

Histology and electron microscopy. A piece of tissue was fixed in buffered formalin and embedded in paraffin. Sections were stained with hematoxylin and eosin. For electron microscopy, pieces of about $1 \mathrm{~mm}^{3}$ were processed according to standard procedures $[18,19]$.

Immunobistochemistry. Pieces of tissue were snap-frozen. The specimen from patient KD was stored for 6 years in liquid nitrogen and that from patient TF for 2 years at $-70^{\circ} \mathrm{C}$ before analysis in this study. Cryostat sections of 4-6 $\mu \mathrm{m}$ thickness were air-dried and fixed in acetone for $10 \mathrm{~min}$ at room temperature, followed by rinsing in PBS. In immunoperoxidase staining with mouse monoclonal antibodies a two-step procedure was followed: (1) incubation with antibody solution at predetermined optimal dilution in PBS with $1 \%$ (wt/vol) human serum 
TABLE 1 Immunological data in two patients with the "bare lymphocyte" syndrome ${ }^{a}$

Humoral immunity

serum Ig

specific antibodies

bone marrow plasma cells

blood surface $\lg$ positive cells

\section{Cell-mediated immunity}

blood lymphocytes $\left(\times 10^{\circ} / \mathrm{L}\right)$

sheep erythrocyte rosetting cells $(\%)$

delayed hypersensitivity to recall antigens

in vitro proliferative responses

mitogens (PHA, ConA, PWM)

allogeneic cells

recall antigens

in vitro differentiation into cytoplasmic Ig positive cells

after PWM stimulation

$H L A$ antigens on blood lympbocytes ${ }^{b}$

HLA-A,B,C

HLA-DR

$\beta_{2}$-microglobulin hypogammaglobulinemia

not detectable

few cytoplasmic IgM positive cells

normal

1-3 (KD), 2-4 (TF)

50-60 (KD), 54-90 (TF)

negative

positive

normal (KD), variable (TF)

negative

negative

not detectable

inconclusive (KD)

not detectable (TF)

present on B lymphocytes (KD)

not detectable (TF)

${ }^{a}$ Data from [13] (KD) and [12] (TF).

${ }^{b}$ Data of routine immunofluorescence or cytotoxicity assays. In FACS analysis, HLA-A,B,C expression was found in very low density on cells of patient TF, but there was no detectable HLA-DR expression ([17], Heijnen et al., manuscript in preparation). HLA-DR typing of blood lymphocytes from patient KD yielded inconclusive results, with two out of six anti-DR alloantisera being positive [13].

albumin (Behringwerke, Marburg/Lahn, W. Germany); (2) incubation with horseradish peroxidase-conjugated rabbit Ig to mouse Ig (Dakopatts, Copenhagen, Denmark), diluted 1:40 in PBS with 2.5\% human AB serum. The staining was performed with 3-amino-9-ethylcarbazol (Aldrich Chemical Co., Milwaukee, WI) and $\mathrm{H}_{2} \mathrm{O}_{2}$ in 0.1-M acetate buffer, $\mathrm{pH}$ 4.6. Sections were embedded in an aqueous solution of gelatin $(18 \% \mathrm{wt} / \mathrm{vol})$, glycerin $(50 \% \mathrm{vol} / \mathrm{vol})$, and phenol ( $1 \% \mathrm{wt} / \mathrm{vol})$. With rabbit antibodies a similar technique was followed, using horseradish peroxidase-conjugated swine Ig to rabbit Ig (Dakopatts) diluted 1:60 in the second step.

In double immunofluorescence using mouse and rabbit antibodies, a two-step incubation with mouse monoclonal antibody and FITC-labeled goat anti-mouse IgG or IgGl antibody (GAM/FITC or GAM/IgGI/FITC, Nordic Immunological Laboratories, Tilburg, The Netherlands) was followed by a two-step incubation with rabbit antibody and TRITC-labeled goat anti-rabbit Ig (GAR/TRITC, Nordic). Sections were embedded in a PBS:glycerin (9:1) mixture and read using a fluorescence microscope equipped with epi-illumination (Ortholux II, Leitz, with XB075 illumination and a I2 or K2 (FITC) and N2 (TRITC) filter combination, $25 \mathrm{x}$ or $40 \mathrm{x}$ water immersion objectives, $12.5 \mathrm{x}$ oculars). In controls there was no apparent reactivity of anti-rabbit antibody to mouse $\mathrm{Ig}$ or of anti-mouse antibody to rabbit Ig.

For detection of $\mathrm{T}$ and $\mathrm{B}$ cell antigens, various monoclonal mouse antibodies of the Leu series (Becton Dickinson, Mountain View, CA) and OKT series (Ortho 
TABLE 2 Expression of $T$ cell antigens on thymocytes

\begin{tabular}{lll}
\hline \multicolumn{1}{c}{ Antigen } & $\begin{array}{c}\text { Thymocytes in } \\
\text { suspension, } \\
\text { patient TF } \\
\text { Leu 1 }\end{array}$ & not done \\
$\begin{array}{l}\text { OKT 3 } \\
\text { OKT 4/Leu 3a }\end{array}$ & $\begin{array}{c}\text { Thymus tissue section } \\
\text { patient KD and TF }\end{array}$ \\
OKT 8/Leu 2a & 84 & $\begin{array}{l}\text { weak intensity on cortical thymocytes, } \\
\text { strong intensity on medullary } \\
\text { thymocytes } \\
\text { thymocytes in medulla } \\
\text { cortical thymocytes, majority of } \\
\text { medullary thymocytes }\end{array}$ \\
$\begin{array}{l}\text { OKT 6 } \\
\text { PNA binding }\end{array}$ & 87 & $\begin{array}{l}\text { cortical thymocytes, scattered thymocytes } \\
\text { in medulla } \\
\text { TdT }\end{array}$ \\
surface Ig & 96 & $\begin{array}{l}\text { cortical thymocytes } \\
\text { cortical thymocytes } \\
\text { not done } \\
\text { negative }\end{array}$ \\
\hline
\end{tabular}

Diagnostic Systems Inc., Raritan, NJ) were applied (listed in Table 2). PNA binding capacity was assessed by direct immunofluorescence with FITC-labeled PNA (Vector, Burlingame, CA) [20]. Surface Ig expression was investigated in direct immunofluorescence with combinations of FITC-conjugated anti- $\kappa$, anti- $\lambda$ (Behringwerke), anti-IgM (Dakopatts), anti-IgG (Kallestad, Austin, TX) or anti-IgA (Hyland) and TRITC-conjugated anti- $\lambda$ or anti- $\kappa$ (Dakopatts).

For identification of epithelial cells, rabbit antibody to human keratin (kindly provided by Professor G. Janossy and Dr. L. K. Trejdosiewicz, London, England [21], or obtained commercially (Dakopatts)) was applied. Both antisera gave similar results in immunohistochemistry. For detection of thymosin components, rabbit antisera to bovine thymosin fraction 5 (G95K) and fraction 6 (G95L), synthetic thymosin $\alpha_{1}$ (G56), synthetic thymosin $\beta_{4}$ (G85), and thymosin $\alpha_{7}$ (G64) were kindly provided by Professor A. L. Goldstein, Washington, DC. These were applied in indirect immunofluorescence on frozen tissue sections. In addition, thymosin fraction 5 and 6 were detected on sections of sublimate formaldehydefixed tissue embedded in paraffin, using a three-step immunoperoxidase method $[22,23]$.

For detection of HLA antigens, various antibodies were applied. The common determinant of HLA-A,B,C was detected with mouse monoclonal antibody clone W6/32 HLK, clone 34/28 HLK (both from Sera-Lab, Crawley Down, England), and clone B9.12.1 (kindly provided by Dr. B. Malissen, Marseille, France). In addition, rabbit anti-human $\beta_{2}$-microglobulin was applied (Dakopatts). For detection of class II antigens, monoclonal mouse antibodies to nonpolymorphic determinants were used: anti-HLA-DR (Becton Dickinson); anti-human DR antigen (Bethesda Research Laboratories, Gaithersburg, MD); OkIal (Ortho); anticlass II (DR, DC, SB, MT), clone 7.5.10.1 (kindly provided by Dr. F. Koning, Leiden, The Netherlands); anti-HLA-DR, clone 8.11.2 (provided by Dr. F. Koning); anti-HLA-DC/DS, clone SPV-L3 (kindly provided by Dr. H. Spits, Amsterdam, The Netherlands [24]). In some experiments, a FITC-labeled monoclonal mouse anti-HLA-DR antibody was applied (provided by Professor G. Janossy, London, England).

Thymocyte cytology. A part of the biopsy from patient TF was minced into small fragments, followed by harvesting of thymocytes in suspension. Cytocentrifuge 
preparations were stained with May-Grünwald-Giemsa. The expression of T cell antigens detected by monoclonal antibodies (Table 2) and HLA antigens (Table 4) has been reported previously (experiments in collaboration with Dr. A. Astaldi and R. van de Griend, Central Laboratory of the Netherlands Red Cross Blood Transfusion Service, Amsterdam, The Netherlands) [12]. PNA binding capacity was assessed on cells in suspension using FITC-labeled PNA in direct immunofluorescence, and TdT was determined on cytocentrifuge preparations in indirect immmunofluorescence [20,25].

Epithelial cell culture. Minced fragments of the biopsy from patient TF were desintegrated by treatment with collagenase $(2 \mathrm{mg} / \mathrm{ml}, 155 \mathrm{U} / \mathrm{mg}$, Millipore Co., Freehold, NY) in Hepes (25-mM) buffered RPMI-1640 (Gibco, Grand Island, $\mathrm{NY}$ ) for $2 \mathrm{hr}$ at $37^{\circ} \mathrm{C}$. After washing, the fragments were cultured in RPMI-1640 with bicarbonate, L-glutamin $(2 \mathrm{mM})$, penicillin $(100 \mathrm{U} / \mathrm{ml})$, streptomycin $(100$ $\mu \mathrm{g} / \mathrm{ml}$ ), and $20 \%$ human $\mathrm{AB}$ serum, at $37^{\circ} \mathrm{C}$ in humidified air with $5 \% \mathrm{CO}_{2}$. After one week of culture, the medium was exchanged twice weekly. The supernatants were assessed for biological activity in PHA stimulation tests using mouse thymocytes (proliferative responses after ${ }^{3} \mathrm{H}$-thymidine incorporation) [26]. The potentiating effect was calculated as the mean counts per min in PHA stimulated cultures with added supernatant (dilution 1:15, 1:30, and 1:60) divided by the mean counts per minute in PHA stimulated cultures without supernatant. As a control, supernatants were added to PHA unstimulated cultures. Each culture was performed in quadruplicate.

\section{RESULTS}

\section{Light-Microscopic and Electron-Microscopic Histology}

The thymus biopsy of both patients showed a normal lobulated architecture with distinct cortex-medulla areas, well-differentiated epithelium, and Hassall's corpuscles. The cortex and medulla contained numerous lymphocytes. In $1-\mu \mathrm{m}$ sections of the cortex, epithelial cells with a low affinity for stains were most abundant. There were clusters of lymphocytes surrounded by a rim of cytoplasm, with a "pale" cell nucleus apparently belonging to an epithelial cell (Figure 1A). These clusters resembled "Thymic Nurse Cells" described previously [18]. In electron microscopy, most epithelial cells in the cortex had an euchromatic irregularly shaped nucleus with a prominent nucleolus. To a lesser extent, epithelial cells with a heterochromatic nucleus were observed (Figure 1B). In the medulla, there were Hassall's corpuscles of varying size. Epithelial cells with an irregular nucleus with a large prominent nucleolus were most abundant. In light-microscopic histology, as well as in ultrastructural cytomorphology, both thymic biopsies did not differ from the normal appearance for age [19].

\section{Immunohisto- and Cytochemistry of Thymocytes}

Frozen specimens stored for up to 6 years were in sufficiently good condition to enable immunohistological investigation. Anti-T lymphocyte antisera of the Leuand $O K T$ series gave staining patterns similar to those of normal thymuses (Figure $1 \mathrm{C}$, Table 2). Thymocytes in the cortex showed PNA binding capacity. B lymphocytes, identified by surface Ig expression, were not detectable. In May-Grünwald-Giemsa stained cytocentrifuge preparations of thymocytes (patient TF), about $70 \%$ of cells were small thymocytes with absent or scanty cytoplasm, $15 \%$ were intermediate sized cells with little cytoplasm, and $13 \%$ were large lymphoblastoid cells with abundant cytoplasm. Two percent of cells were identified as 


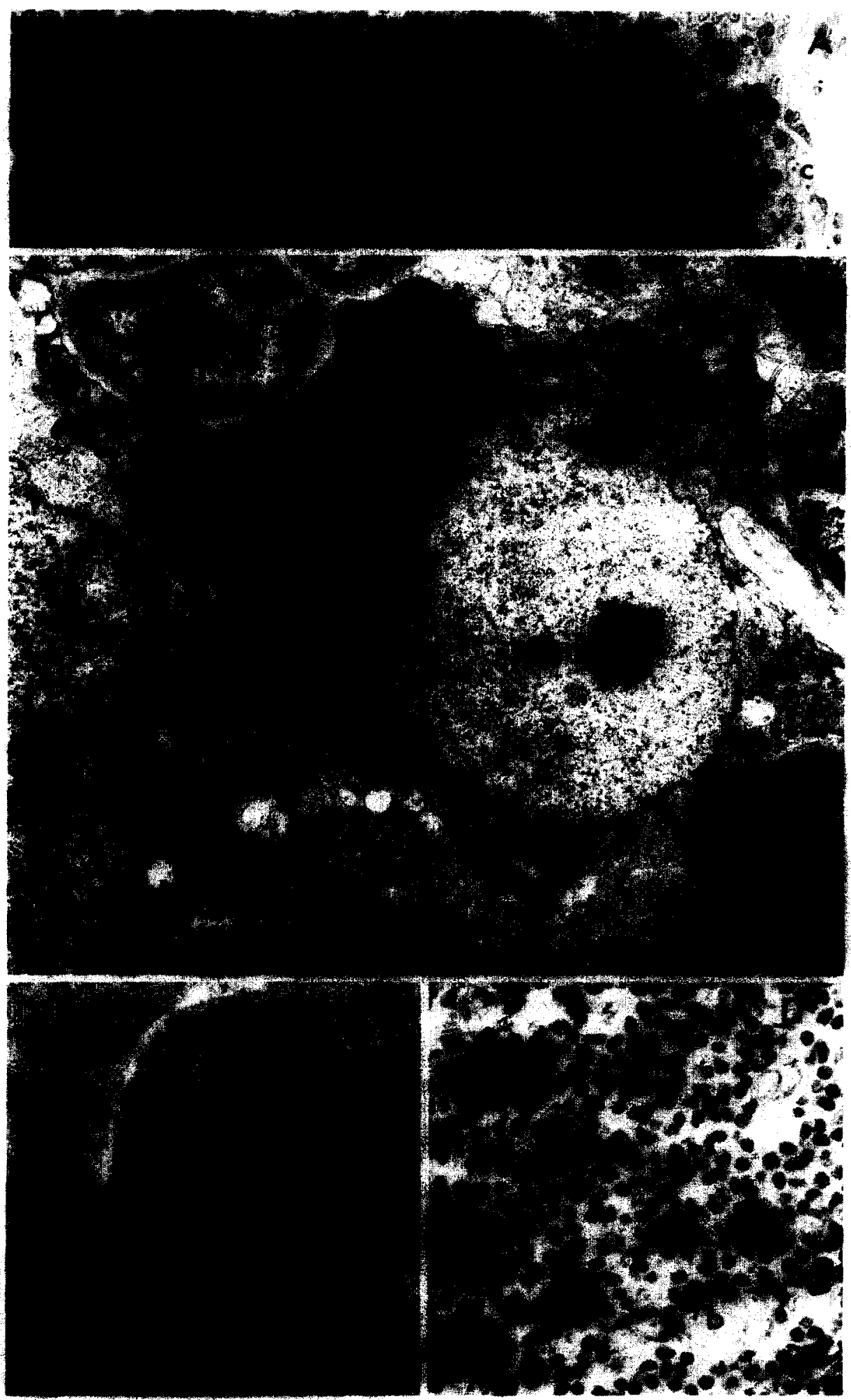


FIGURE 1 Histology of the thymic biopsy from patient TF. A. One $\mu \mathrm{m}$ section of cortical area (pararosaniline and methylene blue staining). Note the presence of large lymphoblastoid cells (a) and mitotic figures (b). Some epithelial cells are indicated (c). There is a cluster of lymphocytes with an epithelial cell nucleus resembling "Thymic Nurse Cells" (d) $\times 260$. B. Electron micrograph of two epithelial cells in the cortex. Epithelial cell characteristics, desmosomes (a) and tonofilaments (b) are indicated. One of the cells shows an euchromatic nucleus with marginal heterochromatin and a prominent nucleolus. In its cytoplasm cisternae of rough endoplasmic reticulum (c), a Golgi complex (d), and mitochondria (e) are present. The other cell contains a heterochromatic nucleus, dilated cisternae of nucleus and rough endoplasmic reticulum $(\mathrm{f})$, swollen mitochondria $(\mathrm{g})$, and vacuoles (h). These cells resemble "pale" and "intermediate" types of epithelial cells, respectively, and may represent stages in a differentiation process within the epithelial cell population [19] $\times 7200$. C. Frozen tissue section stained with anti-Leu 1 (pan-T cell reagent) in an indirect immunoperoxidase method. $T$ lymphocytes in the cortex (a) are less intensely stained than in the medulla $(b) \times 110$. D. Paraffin section of sublimate formaldehyde-fixed tissue stained with anti-thymosin fraction 5 antibody in an indirect immunoperoxidase method, and counterstained with hematoxylin. Some thymosin positive cells in the medullary area are indicated (a). (b), Hassall's corpuscle $\times 440$.

macrophages. One percent of cells was in mitosis. In marker tests, $99 \%$ of cells formed rosettes with sheep erythrocytes. These data and those for other markers (Table 2) did not differ from normal values [20,25] except for the expression of OKT 6 by $96 \%$ of the cells (normal value \pm SD $74 \pm 10 \%$ ).

\section{Immunohistochemistry of Epithelial Cells}

Anti-keratin antibodies showed strong staining intensity of epithelial cells in the subcapsular area and in the medulla (including Hassall's corpuscles). The staining intensity of epithelial cells in the cortex was somewhat less. Thymosin fraction 5 and fraction 6 positive cells were found throughout the cortex and medulla (Figure 1D); thymosin $\alpha_{1}$ positive cells were observed in the subcapsular region, along blood capillaries, and scattered through the medulla. There were thymosin $\beta_{4}$ cells in the subcapsular region, and Hassall's corpuscles and adjacent cells were thymosin $\alpha_{7}$ positive. These findings were similar to those in normal thymuses $[22,23]$.

\section{Epithelial Cell Culture}

In cell culture (patient TF) there was an outgrowth of polygonal epithelial-like cells into a confluent monolayer after about 10-12 days. The supernatant of this culture, harvested after 12, 16, and 21 days of culture, enhanced the proliferative response in PHA stimulation of mouse thymocytes four- to 16-fold (Table 3). Among the dilutions tested, the maximum enhancing effect was observed for 1:15 diluted supernatant. As a control, pooled normal thymus epithelial cell culture supernatant gave a seven- to ten-fold increase of the proliferative response, being maximal at dilution 1:30. There was no effect of epithelial cell culture supernatants on unstimulated cultures of mouse thymocytes.

\section{Expression of HLA Antigens}

In normal thymus tissue sections, antisera to HLA-A,B,C gave a dendritic staining pattern of stromal cells in the cortex and a confluent staining pattern of stromal cells in the medulla. Lymphocytes in the medulla also expressed HLA-A,B,C 
TABLE 3 Potentiating effect of thymic epithelial cell culture supernatant ${ }^{a}$

\begin{tabular}{lcccc}
\hline Supernatant harvested & Day 12 & Day 16 & Day 21 & $\begin{array}{c}\text { Control pooled } \\
\text { thymus epithelial } \\
\text { cell culture } \\
\text { supernatant }\end{array}$ \\
\hline dilution $1: 15$ & 14 & 10 & 16 & 7 \\
dilution $1: 30$ & 7 & 7 & 12 & 10 \\
dilution $1: 60$ & 4 & 4 & 5 & 8
\end{tabular}

“Data from patient TF. Potentiating effects are calculated as the mean ${ }^{3} \mathrm{H}$-thymidine incorporation in PHA stimulated cultures with supernatant divided by the mean ${ }^{3} \mathrm{H}$-thymidine incorporation in PHA stimulated cultures without supernatant. There was no effect of culture supernatants on PHA unstimulated cultures.

(Figure 2A). In double immunofluorescence, using both anti-HLA-A,B,C and anti-keratin antibody, keratin-positive epithelial cells in cortex and medulla were found to be HLA-A,B,C positive. In the patients' biopsies, HLA-A,B,C expression was not detectable on stromal cells in the cortex; only with monoclonal antibody B9.12.1 was there a faint staining of nonlymphoid elements in the cortex, presumably confined to blood vessels. In the medulla, lymphocytes and part of keratin-positive epithelial cells were found HLA-A,B,C positive (Figure 2B). For patient TF, HLA-A,B,C expression on medullary thymocytes was concordant with the $19 \%$ HLA-A and $24 \%$ HLA-B positive cells found in the thymocyte suspension (Table 4).

Expression of $\beta_{2}$-microglobulin in normal thymuses was observed with weak intensity on cortical thymocytes and with strong intensity on medullary lymphoid cells. In addition, stromal components including blood vessels were found positive. In thymus sections of the patients, similar staining patterns, but in weaker staining intensity, were observed. However, there was almost no staining of nonlymphoid cells in the cortex. The $9 \% \beta_{2}$-microglobulin positive cells in the thymocyte suspension of patient TF (Table 4) may be of medullary origin, where the strongest expression in immunohistochemistry was found.

Antisera to HLA class II antigens gave in normal thymuses a dendritic staining pattern of stromal cells in the cortex, and a confluent staining pattern of stromal cells in the medulla (Figure 2C). Lymphocytes appeared to be negative. In double immunofluorescence, keratin-positive cells in cortex and subcapsular area were found to be positive for HLA class II antigens, whereas the major part of keratin positive cells in the medulla were found to be negative. Conversely, the major part of nonlymphoid cells in the medulla expressing HLA class II antigens appeared to be keratin negative. In thymus tissue sections from the two patients there was no detectable HLA class II antigen expression on epithelial cells in the cortex. In the medulla of the thymus from patient KD, antisera to HLA-DR and the monoclonal antibody 7.5.10.1 gave staining of some nonlymphoid cells, whereas anti-HLA-DC/DS gave no staining (Figure 2D). In double immunofluorescence, HLA-DR expressing nonlymphoid cells of patient KD proved to be keratin negative.

The data on HLA antigen expression in the thymus from patients and controls are summarized in Table 4.

\section{DISCUSSION}

The thymic histology of patients with various forms of combined immunodeficiency or T-lymphocyte deficiency has generally been described as abnormal [27]. 

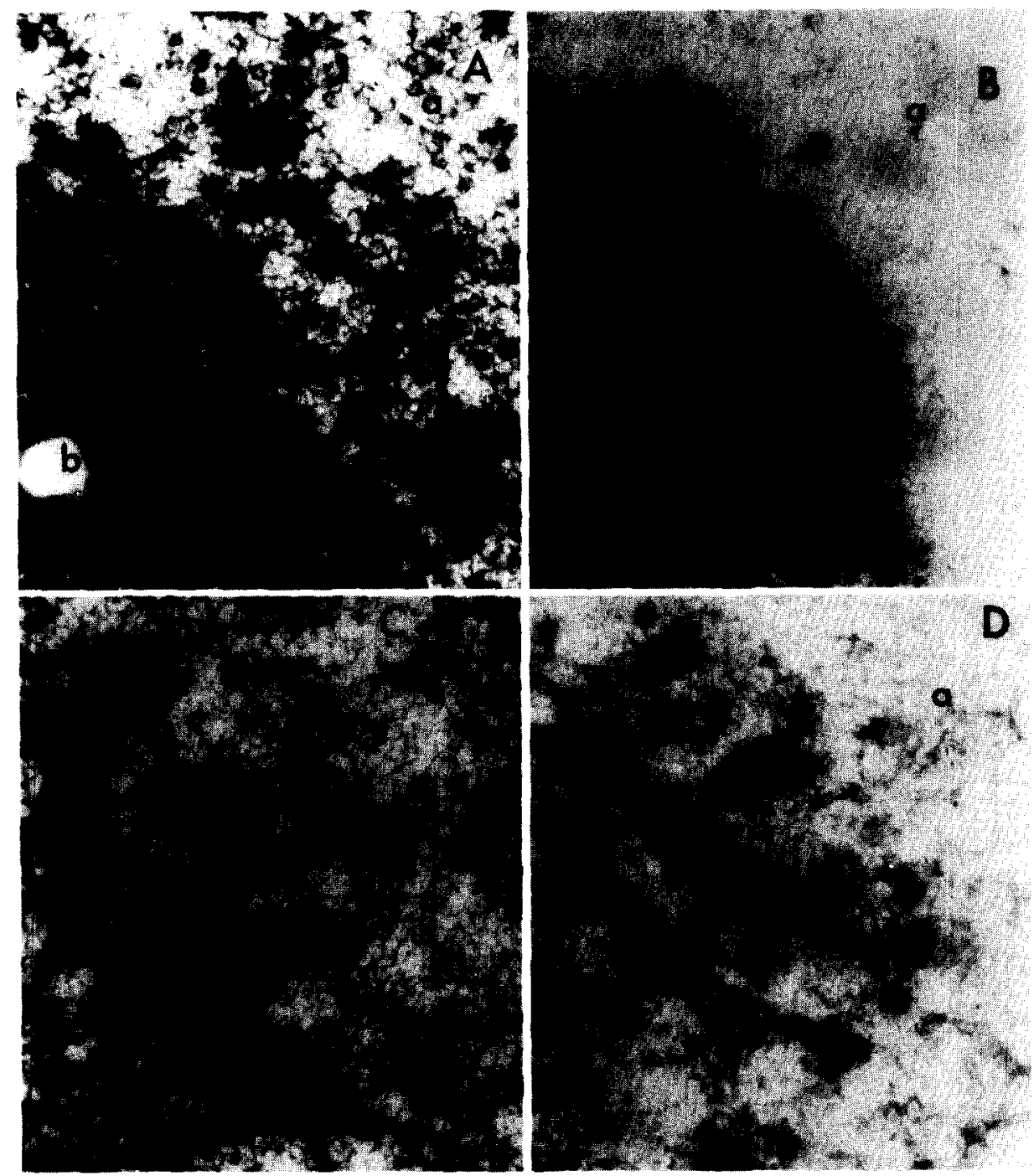

FIGURE 2 Presence of HLA antigens in frozen thymus tissue sections, detected by an indirect immunoperoxidase method. A. HLA-A,B,C is present in normal thymus on stromal cells in the cortex (a) and on stromal cells and lymphocytes in the medulla (b) (monoclonal antibody B9.12.1). B. In thymus from patient KD, there is an almost exclusive staining of stromal cells (a) and lymphocytes in the medulla (b) (antibody B9.12.1). C. HLA-DR expression in normal thymus is observed on stromal cells in cortex (a) and medulla (b) (monoclonal antibody 8.11.2). D. In thymus from patient KD, there is only staining of stromal cells (a) in the medulla (b) (antibody 8.11.2) $\times 300$.

For patients with "bare lymphocyte" syndrome Touraine et al. $[14,15]$ have observed severe thymic hypoplasia at necropsy. In contrast, we found the architecture of thymic biopsy material obtained during life from two patients with "bare lymphocyte" syndrome to be normal. This discrepancy may be primarily ascribed to the general fact that at autopsy after any long and debilitating illness (even for patients with nonimmunologic disorders) the thymus shows severe 


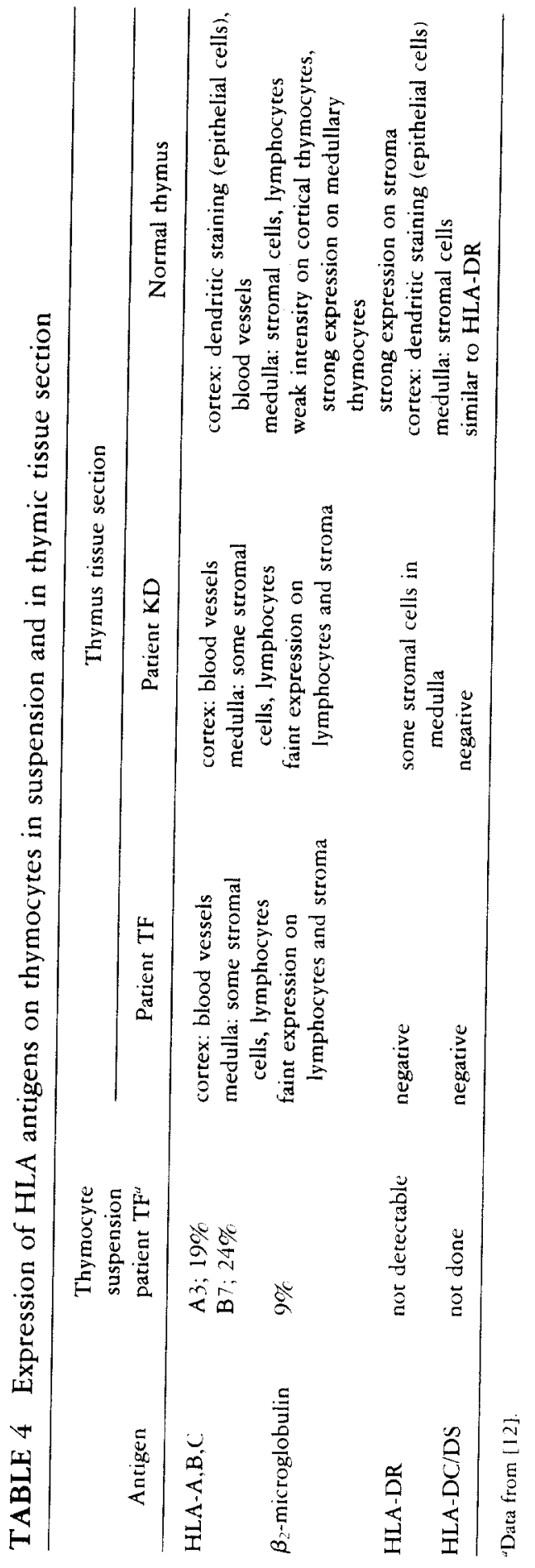


lymphocyte depletion, involution, and collapse of the whole framework of the organ.' In both cases investigated, light- and electron-microscopic histology, 'T-lymphocyte antigen expression, and expression of thymosin components by epithelial cells, did not differ from the normal figures for age. We therefore conclude that $\mathrm{T}$-cell maturation processes, at least those resulting in changes of phenotypes, occur normally in the thymus of both patients.

In normal thymuses about $20 \%$ of lymphoid cells express $\mathrm{HLA}-\mathrm{A}, \mathrm{B}, \mathrm{C}$ antigens $[25,28]$, which cells reside in the medulla $[6,28]$. In studies on mice it has been shown that lymphocytes leaving the thymus express MHC class I antigens in high density [29]. In man the characteristics of thymic emigrant cells are unknown. In the biopsies from the patients we observed HLA-A,B,C expression on medullary thymocytes, which was confirmed for patient TF by analysis of thymocytes in suspension (Table 4). However, HLA-A,B,C expression was not detectable on peripheral blood cells by conventional immunofluorescence or cytotoxicity assays. In FACS analysis, HLA-A,B,C expression was found in very low density on blood cells of patient TF (Table 1). Thus, medullary thymocytes appear to express HLA-A,B,C antigens in higher density than blood lymphocytes in the patients. A similar phenomenon may occur for $\beta_{2}$-microglobulin expression ( $T a-$ bles 1 and 4). This finding indicates that the expression of the defective presence of HLA antigens on lymphocytes varies between lymphocyte populations in different lymphoid compartments. This may also apply to differentiation antigens, as there was a partial deficiency of OKT 3 and OKT 4 antigen expression on blood lymphocytes from patient TF at the time of the thymus biopsy [12]. One may speculate that the thymic micro-environment protects the lymphocytes from abnormalities in expression of membrane antigens.

The main abnormality observed in the thymic biopsies from both patients was the absence of detectable HLA class I and class II antigens on cortical epithelial cells. This abnormality does partly apply to the medulla, where part of epithelial cells lacked HLA-A,B,C expression. The absence of HLA class II antigen expression on epithelial cells in the medulla confirms data of Janossy et al. [6] who used a similar technique. This finding contrasts the results of Rouse et al. [7] who detected HLA-DR antigen on medullary epithelial cells by immunoelectron microscopy. Thus, the HLA-DR positive nonlymphoid cells detected by immunohistochemistry apparently are of other cell types like interdigitating reticulum cells. Evidence for this suggestion comes from reconstitution experiments in irradiated rats, in which Ia-bearing nonlymphoid cells in thymic medulla were of bone marrow origin [30]. In immunohistochemistry with a mouse monoclonal antibody to interdigitating reticulum cells (RFD-1, kindly provided by Professor G. Janossy, London, England), we detected these cells in thymic medulla of both patients and controls. Apparently, these cells do not express HLA-DC/DS antigen in patient $\mathrm{KD}$, and none of HLA class II antigens in patient TF (Table 4).

The findings in our cases with "bare lymphocyte" syndrome shed new light on the significance of $\mathrm{MHC}$ antigen expresssion on epithelial cells in intrathymic lymphoid cell maturation. The normal intrathymic T-cell phenotype expression, in the absence of detectable HLA class I and class II antigens on cortical epithelial cells, prompts us to speculate that the expression of HLA antigens on cortical epithelium plays no significant role in lymphocyte-epithelial cell interaction and in the sequential acquisition of differentiation antigens on $T$ cells in the thymus. This speculation does not apply for processes yielding the antigen recognition repertoire or associated with restriction or amplification of cells with self-MHC receptors. In a separate study on patient TF [16,17, Heijnen et al., manuscript in preparation] we have presented evidence that there is a deletion in helper and suppressor factors produced by peripheral blood lymphocytes from the patient. 
However, we found no formal proof for a lack of the antigen-recognizing part of either the T-cell receptor or of the factors secreted.

\section{ACKNOWLEDGMENTS}

The authors gratefully acknowledge Dr. Thea M. Vroom, Slotervaart Hospital, Amsterdam, The Netherlands, for providing the thymus biopsy specimens from patient KD, and Mr. Roel Broekhuizen for excellent technical assistance. They thank Drs. Coby Heijnen, Wietse Kuis, and Ger Rijkers for stimulating discussions.

\section{REFERENCES}

1. Reinherz EL, Meuer SC, Schlossman SF: The human T cell receptor: analysis with cytotoxic $T$ cell clones. Immunol Rev 74:83, 1983.

2. Thorsby E: The role of HLA in T cell activation. Hum Immunol 9:1, 1984.

3. Wagner H, Hardt C, Stockinger H, Pfizenmayer K, Bartlett R, Röllinghof M: Impact of the thymus on the generation of immunocompetence and diversity of antigenspecific MHC-restricted cytotoxic T-lymphocyte precursors. Immunol Rev 58:95, 1981.

4. Zinkernagel RM, Doherty PC: MHC-restricted cytoroxic T cells: studies on the biological role of polymorphic major transplantation antigens determining $\mathrm{T}$-cell restriction-specificity, function, and responsiveness. Adv Immunol 27:51, 1979.

5. Gelfand EW, Dosch H-M, Shore A, Limatibul S, Lee JWW: Role of the thymus in human $\mathrm{T}$ cell differentiation. In: EW Gelfand, H-M Dosch, Eds. Biological basis of immunodeficiency. New York, Raven Press, 1980, p. 39.

6. Janossy G, Bofill M, Trejdosiewicz LK, Chilosi M: Cellular differentiation of lymphoid subpopulations and their microenvironments in the human thymus. In: HK MüllerHermelink, Ed. The thymus: histophysiology and pathology. Berlin, Springer Verlag, in press.

7. Rouse RV, Parham P, Grumet FC, Weissman IL: Expression of HLA antigens by human thymic epithelial cells. Hum Immunol 5:21, 1982.

8. Van Ewijk W, Rouse RV, Weissman IL: Distribution of H-2 microenvironments in the mouse thymus. Immunoelectron microscopic identification of $\mathrm{I}-\mathrm{A}$ and $\mathrm{H}-2 \mathrm{~K}$ bearing cells. J Histochem Cytochem 28:1089, 1980.

9. Savino W, Dardenne M, Papiernik M, Bach J-F: Thymic hormone-containing cells. characterization and localization of serum thymic factor in young mouse thymus studied by monoclonal antibodies. J Exp Med 156:628, 1982.

10. Jenkinson EJ, van Ewijk W, Owen JJT: Major histocompatibility complex antigen expression on the epithelium of the developing thymus in normal and nude mice. $\mathrm{J}$ Exp Med 153:280, 1981.

11. Lisowska-Gros Pierre B, Durandy A, Virelizier J-L, Fischer A, Griscelli C: Combined immunodeficiency with defective expression of HLA: modulation of an abnormal HLA synthesis and functional studies. In: RJ Wedgwood, FS Rosen, NW Paul, Eds. Primary immunodeficiency diseases. Birth defects, original article series, vol 19. New York, Liss, 1983, p. 87.

12. Kuis W, Roord J, Zegers BJM, Schuurman RKB, Heijnen CJ, Baldwin WM, Goulmy E, Claas F, van de Griend RJ, Rijkers GT, van Rood JJ, Vossen JM, Ballieux RE, Stoop JW: Clinical and immunological studies in a patient with the "bare lymphocyte" syndrome. In: J-L Touraine, E Gluckman, C Griscelli, Eds. Bone marrow transplantation in Europe, Vol II. Amsterdam, Excerpta Medica Elsevier, 1981, p. 201.

13. Schuurman RKB, van Rood JJ, Vossen JM, Schellekens PThA, Feltkamp-Vroom 
ThM, Doyer E, Gmelig-Meyling F, Visser HKA: Failure of lymphocyte-membrane HLA-A and -B expression in two siblings with combined immunodeficiency. Clin Immunol Immunopathol 14:418, 1979.

14. Touraine J-L, Bétuel H, Souillet G, Jeune M: Combined immunodeficiency disease associated with absence of cell-surface HLA-A and -B antigens. J Pediatr 93:47, 1978.

15. Touraine J-L: The bare-lymphocyte syndrome; report on the registry. Lancet 1:319, 1981.

16. Zegers BJM, Heijnen CJ, Roord JJ, Kuis W, Schuurman RKB, Stoop JW, Ballieux RE: Defective expression of mononuclear cell membrane HLA-antigens associated with combined immunodeficiency: impaired cellular interaction. In: RJ Wedgwood, FS Rosen, NW Paul, Eds. Primary immunodeficiency diseases. Birth defects, original article series vol 19. New York, Liss, 1983, p. 93.

17. Zegers BJM, Heynen CJ, Roord JJ, Kuis W, Stoop JW, Ballieux RE: Combined immunodeficiency with defective expression of HLA-antigens: analysis of the nature of the defective monocyte-T cell interaction. In: C Griscelli, JM Vossen, Eds. Progress in immunodeficiency research and therapy, Vol I. Amsterdam, Excerpta Medica Elsevier, 1984, p. 35.

18. Van de Wijngaert FP, Rademakers LHPM, Schuurman H-J, de Weger RA, Kater L: Identification and in situ localization of the "thymic nurse cell" in man. J Immunol 130:2348, 1983.

19. Van de Wijngaert FP, Kendall MD, Schuurman H-J, Rademakers LHPM, Kater L: Heterogeneity of epithelial cells in the human thymus. An ultrastructural study. Cell Tissue Res 237:227, 1984.

20. Schuurman HJ, Klerx JPAM, Van den Brink E, Figdor CG, Kater L: Lymphocyte differentiation in the human thymus: characteristics and function of human thymocyte subpopulations. Hum Lymphocyte Differentiation 1:263, 1981.

21. Trejdosiewicz LK, Smolira MA, Hodges GM, Goodman SL, Livingston DC: Cell surface distribution of fibronectin in cultures of fibroblasts and bladder derived epithelium: SEM-immunogold localization compared to immunoperoxidase and immunofluorescence. J Microsc 123:227, 1981.

22. Kater L, Oosterom R, McClure J, Goldstein AL: Presence of thymosin-like factors in human thymic epithelium conditioned medium. Int J Immunopharmacol 1:273,1979.

23. Schuurman HJ, Van de Wijngaert FP, Delvoye L, Broekhuizen R, McClure JE, Goldstein AL, Kater L: Heterogeneity and age dependency of human thymus reticuloepithelium in production of thymosin components. Thymus 7 ; in press.

24. Spits H, Borst J, Giphart M, Coligan J, Terhorst C, de Vries JE: HLA-DC antigens can cerve as recognition elements for human cytoxic $\mathrm{T}$ lymphocytes. Eur $\mathrm{J}$ Immunol 14:299, 1984.

25. Schuurman HJ, Brekelmans P, Daemen T, Broekhuizen R, Kater L: T-cell maturation in the human thymus and tonsil: peanut agglutinin binding $T$ lymphocytes in thymus and tonsil differ in maturation stage. Clin Immunol Immunopathol 29:271, 1983.

26. Oosterom R, Kater L, Oosterom J: Effects of human thymic epithelial conditioned medium on mitogen responsiveness of human and mouse lymphocytes. Clin Immunol Immunopathol 12:460, 1979.

27. Borzy MS, Schulte-Wisserman H, Gilbert E, Horowitz SD, Pellett J, Hong R: Thymic morphology in immunodeficiency diseases: results of thymic biopsies. Clin Immunol Immunopathol 12:31, 1979.

28. Tidman N, Janossy G, Bodger M, Granger S, Kung PC, Goldstein G: Delineation of human thymocyte differentiation pathways utilizing double-staining techniques with monoclonal antibodies. Clin Exp Immunol 45:457, 1981. 
29. Scollay R, Jacobs S, Jerabek L, Butcher E, Weissman I: T cell maturation: thymocyte and thymus migrant subpopulations defined with monoclonal ant/bodies to MHC region antigens. $J$ Immunol 124:2845, 1980

30. Barclay AN, Mayrhofer G: Bone marrow origin of la-positive cells in the medulla of rat thymus. J Exp Med 153:1666, 1981. 